\title{
PELATIHAN KETERAMPILAN KERAMIK SEBAGAI BEKAL HIDUP TUNA WICARA BERBASIS KEMANDIRIAN
}

\author{
Fani Lidiani Lestari ${ }^{1}$, Iis Nurhayati ${ }^{2}$ \\ 1, 2 Program Studi Pendidikan Masyarakat IKIP Siliwangi, Cimahi, Jawa Barat, Indonesia \\ ${ }^{1}$ fwidiani@gmail.com
}

Received: Agustus, 2020; Accepted: September, 2020

\begin{abstract}
The limitation in speaking makes it difficult for the speech impaired to communicate with people around them in everyday life, therefore the ability to develop their skills is very limited. The Kubca Samakta Foundation has a ceramic making program to develop life skills (like skills) of speech impaired people. This study aims to determine the ability of speech impaired people to develop their life skills and make mute mute independent. This can encourage the speech impaired to develop life skills to be more skilled and focused. This research uses descriptive qualitative methods. The research subjects were 7 people 1 chairman of the Kubca Samakta Foundation 1 master of ceramic skills. The results showed that at this foundation there were 5 people who had participated in the ceramic making program. They were all people who had limitations, but their enthusiasm for learning was high. The results of this ceramic making make them skilled, able to develop their life skiing through the ideas they have. Their attitude was very enthusiastic about holding this ceramic making program, they became more skilled in developing their talents. The inhibiting factor is that they have difficulty communicating properly because of the limitations they have. Overall, this program is very good for the development of speechimpaired life skills because they can produce interesting works, and ceramic lovers can enjoy their work. It's just that the difficulty of communicating creates a barrier for them because only certain people understand their sign language.
\end{abstract}

Keywords: training, life skills, communication

\begin{abstract}
Abstrak
Keterbatasan dalam berbica membuat para tuna wicara sulit untuk berkomunikasi dengan orang sekitar dalam kehidupan sehari-hari maka dari itu kemampuan untuk mengembangkan keterampilannya sangat terbatas. Yayasan kubca samakta memiliki program pembuatan keramik untuk mengembangkan kemampuan kecakapan hidup (like skill) para tuna wicara. Penelitian ini bertujuan untuk mengetahui kemampuan tuna wicara dalam pengembangan kecakapan hidup (life skill) yang mereka miliki dan menjadikan tuna wicara mandiri. Hal ini dapat mendorong para tuna wicara untuk mengembangkan kecakapan hidup (life skill) agar lebih terampil dan terarah. Penelitian ini menggunakan metode kualitatif yang bersifat deskriftif. Subjek penelitian 7 orang 1 ketua yayasan kubca samakta 1 pengolala keterampilan keramik. Hasil penelitian menujukan bahwa di yayasan ini sudah ada 5 orang yang mengikuti program pembuatan keramik meraka semua orang-orang yang memiliki keterbatasan, tetapi semangat untuk belajar mereka tinggi. Hasil dari pembuatan keramik ini membuat mereka menjadi terampil, dapat mengembangkan life skiil melalui ide-ide yang mereka punya. Sikap mereka sangat antusias dengan diadakannya program pembuatan keramik ini mereka jadi lebih terampil dalam mengembangkan bakat mereka. Faktor penghambatnya mereka kesulitan berkomunikasi dengan baik karena keterbatasan yang mereka miliki. Secara keseluruhan program ini sangat baik untuk pengembangan life skill tuna wicara karena mereka bisa menghasilkan karya yang menarik, dan karya mereka pun dapat di nikmati oleh para pecinta keramik. Hanya saja kesulitan berkomunikasi membuat hambatan bagi mereka karena hanya orang-orang tertentu saja yang memahami bahasa isyarat yang mereka miliki.
\end{abstract}

Kata Kunci: Pelatihan, life skill, berkomunikasi 
How to Cite: Lestari \& Nurhayati. (2020). Pelatihan Keterampilan Keramik Sebagai Bekal Hidup Tuna Wicara Berbasis Kemandirian. Comm-Edu (Community Education Journal) 3 (3), 188198.

\section{PENDAHULUAN}

Sumber daya manusia pada dasarnya merupakan hal yang unik, terletak pada potensinya untuk tumbuh dan berkembang dalam menghadapi tantangan baru, oleh karena itu, ketika karyawan memandang organisasi sebagai tempat bekerja, maka kesempatan untuk berkembang dan meningkatkan diri menjadi penting bagi mereka. Pengembangan SDM diperlukan karena karyawan, pekerjaan, dan organisasi senantiasa berubah. Pengembangan merupakan upaya memberi kemampuan kepada karyawan yang akan diperlukan di masa yang akan datang. Dalam pengembangan orang harus memiliki motivasi yang datang dari diri sendiri.

Setelah sumber daya manusia diperoleh, perlu dilakukan pengembangan termasuk pengembangan sikap dan skill serta kemampuan yang dilakukan melalui pelatihan-pelatihan. Pengembangan sumber daya manusia merupakan aspek penting dalam meningkatkan keunggulan bersaing organisasi perusahaan.

Menurut definisi World Health Organization (WHO), life skills atau kecakapan hidup adalah kemampuan untuk berprilaku yang adaftif dan positif yang membuat seseorag dapat menyelesaikan kebutuhan dan tantangan sehari-hari dengan efektif. Kecakapan hidup pada dasarnya adalah kemampuan seseorang untuk berjuang berani hidup(survial). Oleh karena itu kecakapan hidup sangat diperlukan bagi setiap individu termasuk orang yang memiliki keterbatasan fisik guna untuk memecahkan permasalahan yang dihadapi. Secara garis besar kecakapan hidup terdiri atas :

Kecakapan hidup yang bersifat generik (Generik Skill), yaitu kecakapan yang diperlukan oleh siapa saja, apapun profesinya dan berapapun usianya dan kecakapan hidup yang spesifik (Specific Skil), yaitu kecakapan hidup yang hanya diperlukan oleh orang yang menekuni profesi tertentu (Sumani, 2006: 93).

Untuk mengembangkan kecakapan hidup (life skill) pada seseorang perlu proses pendidikan dan latihan yang pada dasarnya bertujuan untuk memperoleh kemampuan dasar. Karena tanpa bekal kemampuan dasar, seseorang akan sulit untuk mengembangkan kecakapan hidupnya. Menurut (Satori, D. 2000) :

Mendefinisikan kewirausahaan dengan penekanan pada penciptaan hal-hal baru dikemukakan oleh Joseph Schumpeter (1934) bahwa kewirausahaan adalah melakukan hal-hal baru atau melakukan hal-hal yang sudah dilakukan dengan cara baru, termasuk penciptaan produk baru dengan kualitas baru. Schumpeter mengaitkan kewirausahaan dengan konsep yang diterapkan dalam konteks bisnis dan mencoba menghubungkan dengan kombinasi berbagai sumber daya manusia. Kemampuan dan keinginan manusia dalam berwirausaha merupakan hal penting untuk meningkatkan peluang ekonomi baru.

Saat ini di indonesia dengan jumlah penduduk sebesar 220 juta jiwa membutuhkan sedikitnya 4,4 juta jiwa wirausaha, namun jumlah wirausaha yang ada mencapai 400 ribu jiwa atau kurang dari $1 \%$ populasi penduduk Indonesia. Sementara menurut David McCleland bahwa sebuah 
negara baru bisa maju jika jumlah wirausaha $11,5 \%$ dari populasi penduduknya. Jika melihat kebutuhan wirausaha baru untuk memposisikan Indonesia sebagai negara maju dan estimasi waktu yang cukup lama untuk mencapainya, maka saat ini perlu segera diupayakan langkahlangkah agar jumlah wirausaha baru dapat bertambah dengan waktu pencapaian yang relatif singkat. Salah satu langkah yang dapat dilakukan dengan penciptaan wirausaha baru.

Beberapa faktor yang menjadi kendala yaitu kemandirian. Secara umum kemandirian berasal dari kata "mandiri" yang berarti "diperintah oleh diri sendiri". Ia merupakan kebalikan dari ketergantungan terhadap orang lain. Kemandirian merupakan kemampuan seseorang membuat keputusan bagi dirinya sendiri. Hadari Nawawi menyebutkan beberapa ciri kemandirian, yakni: 1) Mengetahui secara tepat cita-cita yang hendak dicapai. 2) Percaya diridan dapat dipercaya serta percaya pada orang lain. 3) Mengetahui bahwa sukses adalah kesempatan bukan hadiah. 4) Membekali dengan pengetahuan dan keterampilan yang berguna. 5) Mensyukuri nikmat Allah. Saat ini masih ada beberapa orang yang mempunyai keterbatasan fisik maupun mental khususnya bagi orang yang tergolong kepada Tuna Wicara, Menurut Heri Purwanto Tuna Wicara dalam buku Ortopedagogik Umum (1998) apabila seseorang mengalami kelainan baik dalam pengucapan (artikulasi) bahasa maupun suaranya dari bicara normal, sehingga menimbulkan kesulitan dalam berkomunikasi lisan dalam lingkungan. Hal itu menjadi pokok permasalahan penting bagi sebagian masyarakat yang tergolong kedalam Tunawicara sehingga tidak bisa mengembangkan bakatnya dan menyalurkan idenya dalam bersosialisasi, padahal orang yang mengalami Tunawicara hanya saja dalam keadaan fisik, namun dalam segi mental dan intelektual mereka dapat berjalan layaknya orang normal.

Program Pelatihan Keramik dirancang untuk membimbing, melatih dan membelajarkan masyarakat agar memiliki bekal hidup yang cukup untuk menghadapi masa depan. Melalui proses pembelajaran dan pelatihan masyarakat khususnya masyarakat Tunawicara pada akhirnya mampu mengembangkan dirinya dan memiliki keterampilan hidup.

Berkenaan dengan kondisi tersebut maka menjadi perhatian besar oleh Yayasan Kubca Samakta yang merupakan yayasan yang mendirikan pelatihan bekal hidup bagi para penyandang disabilitas untuk dapat membuka kesempatan pelatihan keterampilan bekal hidup dalam menggali potensi atau bakat masyarakat tunawicara yang terletak di kecamatan Lembang.

Dalam paparan diatas maka penulis mengambil judul proposal penelitian "Pelatihan keterampilan keramik sebagai bekal hidup tuna wicara berbasis kemandirian". (Studi kasus keterampilan keramik di Yayasan Kubca Samakta Desa Jayagiri Kecamatan Lembang Kabupaten Bandung Barat)

\section{LANDASAN TEORI \\ Pengertian SDM}

Sumber Daya Manusia adalah penduduk yang siap, mau dan mampu memberikan sumbangan terhadap usaha untuk mencapai tujuan organisasi. Dalam ilmu kependudukan, konsep sumber daya manusia ini dapat disejajarkan dengan konsep tenaga kerja yang meliputi angkatan kerja dan bukan angkatan kerja. Angkatan yang bekerja disebut juga dengan pekerja.Organisasi pada dasarnya merupakan kerja sama antara dua orang atau lebih dalam rangka mencapai suatu tujuan. Organisasi adalah kumpulan orang, proses pembagian kerja antara orang-orang tersebut dan adanya sistem kerja sama atau sistem sosial diantara orang-orang tersebut. 
Dalam mencapai tujuan, organisasi memerlukan berbagai macam sumber daya. Mulai dari sumber daya manusia, peralatan, mesin, keuangan, dan sumber daya informasi. Setiap sumber daya memiliki tugas dan fungsinya masing-masing. Sebagai suatu sistem sumber daya-sumber daya tersebut akan berinteraksi dan saling bekerja sama sehingga tujuan dapat tercapai dengan efektif dan efesien.

Dengan berpijak pada pendekatan sistem, manajemen sumber daya manusia merupakan bagian dari sebuah sistem yang lebih besar yaitu organisasi. Oleh karena itu upaya-upaya sumber daya manusia hendak dievaluasi berdasarkan kontribusinya, berdasarkan produktifitas organisasi. Dalam prakteknya model manajemen sumber daya manusia merupakan sebuah sistem terbuka yang terbentuk dari bagian-bagian yang saling terikat.

Setiap organisasi baik organisasi perusahaa, sosial, pemerintahan mempunyai tujuan yang dapat dicapai melalui pelaksanaan pekerjaan tertentu, dengan mampergunakan sumber daya yang ada pada organisasi. Dan yang paling penting dalam mencapai organisasi adalah sumber daya manusia.

Sumber daya manusia sebagai salah satu sumber daya yang ada dalam organisasi memegang peranan penting dalam keberhasilan pencapaian tujuan organisasi. Berhasil atau tidaknya tergantung pada kemampuan sumber daya manusia dalam menjalankan tugas dan fungsinya, manusia selalu berperan aktif dan selalu dominan dalam setiap aktifitas organisasi, karena manusia menjadi perencana, pelaku, sekaligus penentu terwujudnya tujuan organisasi.

Manajemen sumber daya manusia kedudukannya sangat penting bagi organisasi. Oleh karena itu dalam mengelolanya, mengatur dan memanfaatkan sumber daya manusia akan berjalan sesuai apa yang diharapkan. Sehingga dapat berfungsi secara produktif untuk tercapainya tujuan organisasi.

\section{Teori Pelatihan}

Istilah pelatihan tidak terlepas dari latihan karena keduanya mempunyai hubungan yang erat, latihan adalah kegiatan atau pekerjaan melatih untuk memperoleh kemahiran atau kecakapan. Sedangkan tujuan kegiatan pelatihan untuk meningkatkan pengetahuan dan keterampilan seseorang agar mereka yang dilatih mendapat pengetahuan dan keterampilan dalam menghadapi masalah yang dihadapi sesuai harapan dan tujuan yang di inginkan mengikuti kegiatan pelatihan.

Menurut simamora dalam Kamil (2010:4), mendefinisikan pelatihan sebagai serangkaian aktivitas yang dirancang untuk meningkatkan keahlian-keahlian, pengetahuan, pengalaman ataupun perubahan sikap sorang individu.

Fiedman dan Yarbrough dalam Sudjana (2007:4) menunjukan bahwa pelatihan adalah upaya pembelajaran, yang diselenggarakan oleh organisasi (instasi pemerintah, lembaga swadaya masyarakat, perusahaan, dan lain sebagainnya) untuk memenuhi kebutuhan atau mencapai tujuan organisasi.

Mils (1973) dalam Kartika (2011:8), pelatihan yang di barengi dengan penuh pengertian merupakan Pendidikan lanjutan dan menjadi dasar lebih luas sehingga pekerja akan menjadi lebih terampil, lebih bahagia dalam pekerjaannya itu dan akan membuat dirinya sadar terhadap kesempatan-kesempatan untuk mencapai kemajuan atau bahkan untuk merubahan latihannya sesuai dengan yang diinginkannya.

Dari pengertian dari beberapa para ahli yang telah dikemukan diatas, pada hakekatnya memiliki pandangan yang sama yaitu bahwa pelatihan baik sebagai lanjutan atau merupakan usaha untuk meningkatkan kualitas sumber daya manusi melalui pembelajaran.

Pada dasarnya pelatihan memiliki unsur-unsur sebagai berikut:

a. Adanya proses pembelajaran yang disengaja, teratur, terencana dan sistematis. 
b. Memiliki tujuan ingin dicapai untuk meningkatkan potensi yang telah ada pada wrga belajar.

c. Memberikan pengetahuan dan keterampilan untuk meningkatkan kemampuan seseorang .baik individu maupun kelompok.

d. Waktu yang diselenggarakan relatif singkat.

\section{Prinsip-prinsip Pelatihan}

Menurut Kamil (2010:11:13) menyebutkan bahwa pelatihan merupakan bagian dari proses pembelajaran, maka prinsip-prinsip pelatihanpun dikembangkan dari prinsip-prinsip pembelajaran. Prinsip umum agar pelatihan berhasil adalah sebagai berikut:

a. Prinsip Perbedaan Individu, Perbedaan-perbedaan individu dalam latar belakang sosial pendidikan, pengalaman, minat, bakat dan kepribadian harus diperhatikan dalam menyelengggarakan pelatihan.

b. Prinsip Motivasi, Agar peserta pelatihan belajar dengan giat perlu adanya motivasi, motivasi dapat berupa pekerjaan atau kesempatan berusaha.

c. Prinsip Pemilihan dan Pelatihan para Pelatih. Efektivitas program pelatihan antara lain bergantung pada para pelatih yang mempunyai minat dan kemampuan melatih. Anggapan bahwa seseorang dapat mengerjakan sesuatu dengan baik akan dapat melatihkannya dengan baik pula tidak sepenuhnya benar. Karena itu perlu adanya pelatihan bagi para pelatih. Selain itu pemilihan dan pelatihan para pelatih dapat menjadi motivasi tambahan bagi peserta pelatihan.

d. Prinsip Hubungan Pelatihan dengan pekerjaan atau dengan Kehidupan Nyata. Pekerjaan jabatan atau kehidupan nyata dapat memberikan informasi mengenai pengetahuan, keterampilan, dan sikap yang dibutuhkan.

\section{Prosedur Pelatihan}

Kamil (2010: 155) Pelaksanaan pelatihan memerlukan prosedur atau langkah-langkah agar pelatihan berjalan dengan baik. Langkah-langkah pelatihan sebagai acuan dalam melaksanakan pelatihan adalah sebagai berikut:

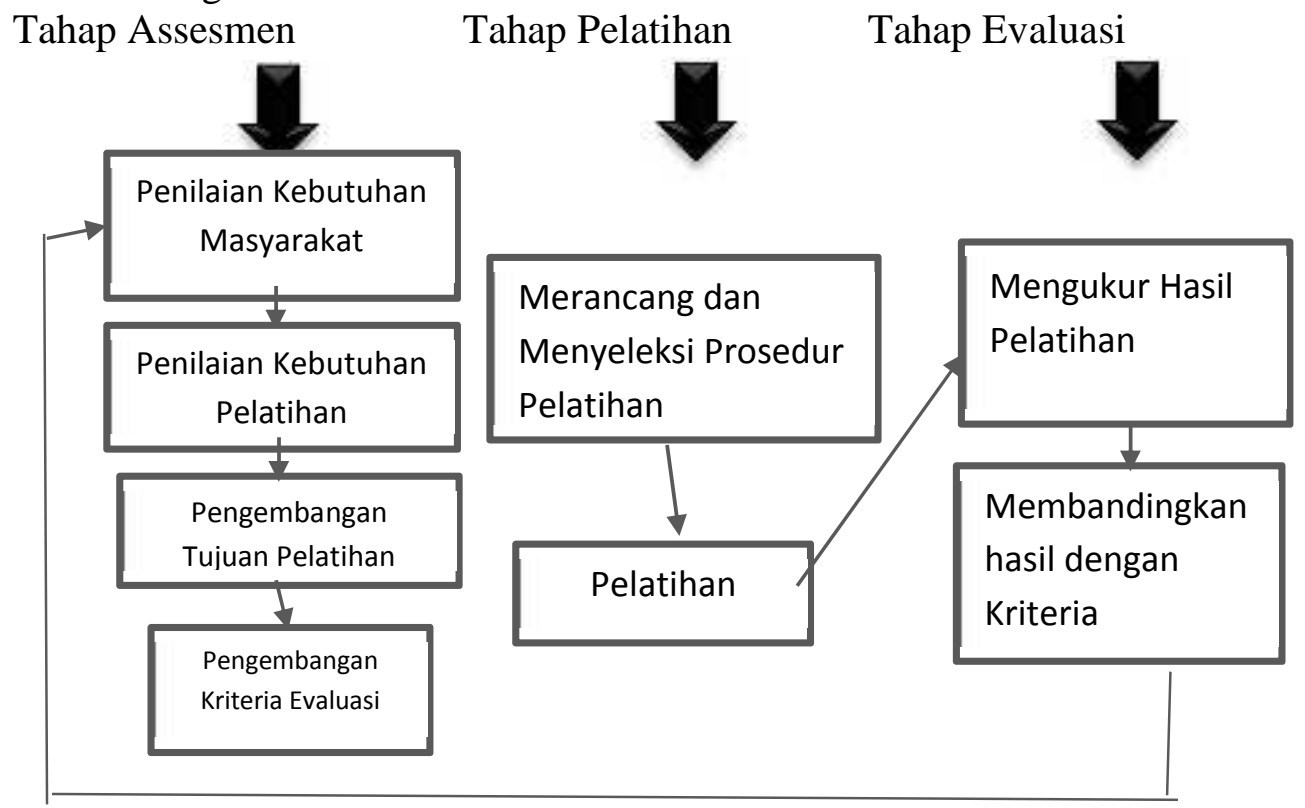

Gambar 2.1 Prosedur Pelatihan Model Proses dalam

(Kamil,2010:155) 
Atas dasar diagram di atas, prosedur pelatihan dimulai dengan analisis kebutuhan yang menjadi pangkal utama dalam penyusunan program pelatihan. Kemudian dilanjutkan dengan penyusunan kriteria keberhasilan sebagai tolak ukur kesuksesan atau kegagalan penyelenggaraan suatu pelatihan. Rancangan dilakukan secermat mungkin agar proses pelatihan berlangsung secara baik dan dapat menghindari faktor-faktor yang mungkin akan menghambat.

Proses pelatihan perlu dievaluasi kriteria yang telah disiapkan sehingga keberhasilan dan kegagalan penyelenggaraan pelatihan dapat diketahui dan dapat digunakan untuk penyusunan prosedur pelatihan berikutnya dengan disertai perbakan seperlunya terhadap diagaram model proses pelatihan yang telah ada.

\section{Teori Lifeskill}

Pendidikan kecakapan hidup menurut Tim BBE Depdiknas (2002) pendidikan kecakapan hidup (Life Skills Education) merupakan proses pendidikan yang mengarah pada pembekalan kecakapan seseorang, untuk mampu dan berani menghadapi problema hidup dan kehidupan secara wajar, tanpa merasa tertekan, kemudian secara proaktif dan kreatif mencari solusinya, sehingga akhirnya mampu mengatasi problema tersebut.

Penjelasan pasal 26 ayat 3 UU No. 20 Tahun 2003 tentang Sistem Pendidikan Nasional menyebutkan bahwa pendidikan kecakapan hidup (life skills education) adalah "Pendidikan yang memberikan kecakapan personal, sosial, intelektual dan kecakapan vokasional untuk bekerja atau usaha mandiri".

Kecakapan hidup adalah kecakapan yang dimiliki seseorang untuk mau dan berani menghadapi problema hidup dan kehidupan secara wajar tanpa merasa tertekan, kemudian secara proaktif dan kreatif mencari serta menemukan solusi sehingga akhirnya mampu mengatasinya (Kamil, 2010: 129).

Pendidikan kecakapan hidup (life skill eduation) adalah pendidikan yang memberikan bekal keterampilan yang praktis, terpakai, terkait dengan kebutuhan pasar kerja, peluang usaha dan potensi ekonomi industri yang ada di masyarakat (Anwar, 2004:20).

Berdasarkan beberapa pendapat para tokoh dapat disimpulkan bahwa pendidikan kecakapan hidup atau life skill merupakan suatu upaya pendidikan untuk meningkatkan suatu kecakapan hidup kepada seseorang dengan memberikan bekal keterampilan yang praktis, yang dapat dipakai didunia kerja, untuk membuka usaha yang dapat digunakan sebagai bekal untuk menghadapi tantangan hidup dan tuntutan kehidupan.

\section{Teori Kewirausahaan}

Joseph Schumpeter (1934) mengemukakan bahwa kewirausahaan adalah melakukan hal-hal baru atau melakukan hal-hal yang sudah dilakukan dengan cara baru, termasuk didalamnya penciptaan produk baru dengan kualitas baru, metode produksi, pasar, sumber pasokan dan organisasi. Schumpeter mengaitkan wirausaha dengan konsep yang diterapkan dalam konteks bisnis dan mencoba menghubungkan dengan kombinasi berbagai sumberdaya. Wennekers dan Thurik (1999) melengkapi pendefenisian kewirausahaan dengan mensintesiskan peran fungsional wirausahawan sebagai: "kemampuan dan kemauan nyata seorang individu, yang berasal dari diri mereka sendiri, dalam tim di dalam maupun luar organisasi yang ada, untuk menemukan dan menciptakan peluang ekonomi baru yang meliputi produk, metode produksi, 
194 Lestari \& Nurhayati, Pelatihan Keterampilan Keramik Sebagai Bekal Hidup Tuna Wicara Berbasis Kemandirian

skema organisasi dan kombinasi barang-pasar serta untuk memperkenalkan ide-ide mereka kepada pasar, dalam menghadapi ketidakpastian dan rintangan lain, dengan membuat keputusan mengenai lokasi, bentuk dan kegunaan dari sumberdaya".

\section{Teori Kemandirian}

Kehidupan manusia saat ini semakin dihadapkan dengan permasalahan yang kompleks. Keadaan ini menuntut setiap individu untuk mampu memecahkan permasalahan yang dihadapi tanpa harus tergantung dengan orang lain dan berani menentukan sikap yang tepat. Salah satu aspek penting yang diperlukan adalah mandiri dalam bersikap dan bertindak.

Menurut Basri (1995) kemandirian berasal dari kata "mandiri" yang dalam bahasa jawa berarti berdiri sendiri. Basri (1995) menyatakan bahwa dalam arti psikologi, kemandirian mempunyai pengertian ssebaai keadaan seseorang dalam kehidupannya yang mampu memutuskan atau mengerjakan sesuatu tanpa bantuan orang lain. Kemampuan tersebut hanya akan diperoleh jika seseorang mampu untuk memikirkan secara seksama tentang sesuatu yang dikerjakannya dan diputuskannya, baik dari segi manfaat atau kerugian yang akan dialaminya.

Siswoyo (Zakiyah,2000) mendefinisikan kemandirian sebagai suatu karakteristik individu yang mengaktualisasikan dirinya, menjadi dirinya seoptimal mungkin dan ketergantungan pada tingkat yang relatif kecil. Orang-orang yang demikian relatif bebas dari lingkungan fisik dan sosialnya. Meskipun mereka tergantung pada lingkungan untuk memuaskan kebutuhan dasar, sekali kebutuhan terpenuhi mereka bebas untuk melakukan caranya sendiri dan menggabungkan potensinya.

Berdasarkan uraian diatas kemandirian dapat disimpulkan sebagai salah satu hal yang dituju dalam perkembangan hidup manusia. Kemandirian didefinisikan sebagai keinginan untuk merasa bebas, berbuat sesuatu atas dorongan sendiri, merasa yakin akan kemampuannya, Mmpu mengatasi masalah, memutuskan atau mengerjakan sesuatu tanpa bantuan orang lain. Sikap mandiri ini dapat dibentuk dari pola interaksi anak dengan orang tua dan keluarganya, sebagai pondasi awal. Sikap mandiri ini perlu diarahkan pada hal-hal yang positif, misalnya untuk melaksanakan tugas sehari-hari, baik dalam lingkungan keluarga maupun masyarakat.

\section{METODE}

Penelitian ini di laksanakan di Yayasan Kubca Samakta (Kelompok Usaha Bersana Penyandang Cacat Jasa Mitra Utama) yang terletak di Jalan Komplek Hortikulturan No 1 Desa Jayagiri Kecamatan Lembang Kabupaten Bandung Barat. Yayasan Kubca Samakta merupakan sebuah organisasi masyarakat yang berfokus pada kegiatan pengembangan diri dan kemandiri bagi remaja dewasa Disabilitas (Tuna Rungu). Dalam proses pelatihan keterampilan Yayasan Kubca Samakta dipilih sebagai tempat belajar para remaja dewasa Disabilitas dikarenakan tempatnya yang strategis.

\section{Subjek Penelitian}

Subjek dalam penelitian kualitatif dinamakan narasumber atau informan subjek dalam Penelitian ini terdiri dari subjek Primer dan subjek Sekunder yang berjumlah 5 orang. Subjek Primer terdiri dari 3 anak binaan yang mengikuti pelatihan keterampilan keramik yang mendapatkan manfaat langsung dari pelatihan keterampilan keramik. Anak binaan terdiri dari 3 anak binaan yang mengikuti pelatihan keterampilan keramik. Anak binaan yang menjadi subjek penelitian adalah remaja dewasa Disabilitas. alasannya karena pelatihan ini khusus untuk remaja dewasa Disabilitas dan mereka memiliki antusias tinggi untuk mengembangkat 
bakat mereka agar menjadi lebih terampil. Subjek sekunder terdiri dari 2 tutor pelatihan keramik.

Prosedur Pengumpulan Data

Peneliti mengambil prosedur penelitian yang dikemukakan berdasarkan langkah fisik (operasional lapangan/pragmentaris) dikarenakan sangat tepat agar peneliti dapat mendapatkan gambaran secara umum baik sebelum, saat dan sesudah agar mendaptkan input, output dan menghasil outcome yang sesuai dan akurat. Dalam buku Metode Penelitian Kualitatif karangan Lexy J. Moleong (2007: 127) dijelaskan bahwa prosedur penelitian terdiri dari tiga tahap, yaitu : tahap pra lapangan, tahap pekerjaan lapangan dan tahap analisis data.

\section{HASIL DAN PEMBAHASAN}

\section{Perencanaan pelatihan keterampilan keramik.}

Berdasarkan informasi yang diperoleh di lapangan pada umumnya perencanaan pelatihan keterampilan ini sangat memberi peluang baik bagi para disabilitas khususnya tuna wicara, pelatihan kemarik merupakan jembatan untuk para kaum disabilitas khususnya tuna wicara untuk menciptakan kemandirian. Dengan menjelaskan tentang latar belakang, visi dan misi Yayasan ini sangat bergua untuk menarik minat para tuna wicara dan dengan startegi yang baik dapat mempengaruhi para tuna wicara untuk mengikuti pelatihan keramik. Yayasan kubca samakta ingin menciptakan para tuna wicara yang mandiri dan berkualitas. Hal ini sejalan dengan teori yang dikemukakan oleh Siswoyo (Zakiyah,2000) mendefinisikan bahwa kemandirian sebagai suatu karakteristik individu yang mengaktualisasikan dirinya, menjadi dirinya seoptimal mungkin dan ketergantungan pada tingkat yang relatif kecil.

\section{Pelaksanaan pelatihan keterampilan keramik}

Berdasarkan informasi yang diperoleh dari lapangan pelaksanaan pelatihan keterampilan keramik dilaksanakan dengan maksimal. Jumlah peserta yang mengikuti dimaksimalkan 15 orang guna untuk memaksimalkan pelatihan dengan baik agar para tuna wicara mendapatkan materi yang baik, karena jika lebih dari 15 orang tutor tidak akan kewalahan dalam memberikan materi tentang pelatihan keramik. Namun pada tahun ini kami hanya bisa merekrut 5 orang saja.

Sistem pembelajaran keterampilan keramik berkelanjutan agar para tunawicara dapat menjadi mahir dalam membuat keramik, karena jika sudah mahir dapat mempraktekan sendiri dan mendapatkan penghasilan sendiri. Maka dari itu para tuna wicara mengikuti pelatihan keterampilan keramik agar meereka menjadi terampil dan dapat menciptakan inovasi-inovasi baru. Jika mereka terampil dalam pembuatan keramik, keramik yang mereka hasilkan pun mendapatkan niali jual yang cukup tinggi. Hal ini sejalan dengan teori yang dikemukakan oleh Mils(1973) dalam (Kartika 2011:8) pelatihan yang dibarengi dengan pengertian merupakan Pendidikan lanjutan dan menjadi dasar lebih luas sehingga pekerja akan menjadi lebih terampil, lebih bahagia dalam pekerjaannya itu.

\section{Hasil pelatihan keterampilan keramik}

Berdasarkan informasi yang diperoleh dari lapangan hasil pelatihan keterampilan berjalan dengan baik karena mereka belajar dengan sungguh-sungguh. Kratifitas mereka pun muncul ketika para tutor memberi kesempatan untuk berinovasi menciptakan hal hal baru dan ketika para tutor menilai hasil pelatihan tersebut sangat memuaskan karena kemarik yang mereka buat tidak asal-asalan sehingga memiliki nilai jual tinggi. Keberhasilan tuna wicara dalam pelatihan keterampilan keramik ini membuat para tutor bangga dan membuat para tuna wicara terampil. 
Mereka yang sudah mahir dalam pembuatan keramik langsung diangkat menjadi pegawai tetap di Yayasan kubca samakta mereka pun di fasilitasi dan diberikan upah yang cukup. Kecakapan hidup adalah kecakapan yang dimiliki seseorang untuk mau dan berani mengahadapi problema hidup dan kehidupan secara wajar tanpa merasa tertekan, kemudian secara proaktif dan kreatif mencari serta menemukan solusi sehingga akhirnya mampu mengatasinya (Kamil, 2010: 129).

\section{Faktor penghambat dalam pelatihan keterampilan keramik.}

Berdasarkan informasi yang diperoleh dari lapangan faktor penghambat dalam pelatihan keterampilan keramik ini adalah dalam proses penyampaian materi tidak dapat sekali langsung dipahami, tetapi harus 2-3 kali dikarenakan mereka memiliki keterbatasan jadi mereka kurang mampu menyerap penyampaian pembelajaran oleh tutor dengan cepat. Perlu beberapa kali pengulangan, hal tersebut sebenarnya menjadi penghambat dalam masalah waktu yang telah di jadwalkan pun terkadang menjadi kurang sesuai dengan yang sudah direncanakan dan daya tangkap tuna wicara pun menjadi penghambat.

Tuna wicara yang putus sekolah terkadang lebih sulit dalam menangkap materi dari tutor beda halnya dengan peserta didik yang lulusan SMA mereka cenderung lebih cepat menangkap materi yang diberikan oleh para tutor. Tetapi para tutor yakin jika mereka semangat mengikuti pelatihan mereka akan lebih cepat dalam memahami materi yang disampaikan oleh tutor. Jika para tuna wicara sudah dapat menangkap materi dengan baik mereka dapat menciptakan peluang kewirausahaan yang baik. Hal ini sejalan dengan yang dikemukakan oleh Wennekers dan Thurik (1999) peran fungsional kewirausahaan sebagai kemampuan dan kemauan nyata seorang individu, yang berasal dari diri mereka sendiri.

\section{KESIMPULAN}

Berdasarkan hasil penelitian yang dipaparkan dapat disimpulkan bahwa, masalah yang dirumuskan sebagaimana disebut dalam bab satu yaitu Apakah benar pelatihan keterampilan keramik telah memberikan sumbangan berarti terhadap keterampilan bekal hidup tuna wicara di yayasan Kubca Samakta, hal ini dibuktikan sebagai berikut :

1. Tahap Perencanaan Pelatihan Keterampilan Keramik

Perencanaan pembelajaran diantaranya dengan tahap - tahap melakukan sosialisasi tentang pelatihan keterampilan keramik, merekrut peserta didik khususnya disabilitas (tuna wicara), memberikan arahan persyaratan yang harus dimiliki peserta didik, membatasi jumlah peserta didik untuk memaksimalkan terlaksananya pelatihan, menyusun strategi agar para tuna wicara berminat untuk mengikuti pelatihan keramik, menyusun langkah langkah program pembelajaran keramik.

2. Tahap Pelaksanaan Pelatihan Keterampilan Keramik

Dalam tahap awal peserta didik diberikan materi dasar dengan diperkenalkan alat-alat yang digunakan dan tahap-tahap pembutan keramik (pengolahan bahan, pembentukan, pengeringan, pembakaran, penggelasiran) dan juga diberi arahan secara umum tentang Teknik-teknik pembuatan keramik.

3. Tahap Hasil Pelatohan Keterampilan Keramik

Dari hasil observasi dan wawancara bahwa Yayasan kubca samakta menjalankan tahapantahapan pelatihan dengan baik, persiapan materi dari para tutor untuk disampaikan terhadap para tuna wicara pun sangat matang. Karena para tutor memang memiliki keinginan besar sekali untuk membuat para tuna wicara ini terampil dalam pembuatan keramik. Tahap pelaksanaan pun dilakukan dengan secara berkelanjutan sampai para tuna wicara mahir dalam pembuatan keramik. Para tutor pun gigih melatih para tuna wicara dengan sabar. Manfaat yang sudah dirasakan oleh para tuna wicara, mereka menjadi mandiri, terampil, 
dapat menciptakan hasil yang baik, mendapat upah yang cukup dari hasil pembuatan keramik.

4. Faktor pendukung dan Penghambat Pelatihan Keterampilan Keramik

Keberhasilan pembelajaran berupa adanya kesungguhan tutornya yang interaktif dan dapat menciptakan iklim atau suasana yag menyenangkan, ketekunan dalam proses pembelajaran serta kesabaran cukup mendukung terjadinya pembelajaran yang interaktif dan menyenangkan, sdedangkan daya dukung dari peserta didik yang mempunyai motivasi yang tinggi pun dapat meningkatkan semangat belajar.

5. Faktor penghambat dikarenakan mereka memiliki keterbatasan jadi mereka kurang mampu menyerap penyampaian pembelajaran oleh tutor dengan cepat. Perlu pengulangan beberapa kali, hal tersebut sebenarnya menjadi penghabat dalam masalah waktu karena waktu yang telah di jadwalkan jadi terkadang kurang sesuai dengan yang sudah direncanakan

\section{DAFTAR PUSTAKA}

Andry, Soepiyah (2014). Strategi kursus dan pelatihan menjahit berbasis life skills: Skipsi PLS IKIP

Bahtiar, E. T. (2015). Penulisan Bahan Ajar. 3(October), 02. https://doi.org/10.1038/jhh.2014.101

Dunnette. (1976). Ketrampilan Mengaktifkan Siswa, Kencana Prenada Media Group : Jakarta

Edwin B. Flippo, Manajemen Personalia, terjemahan Moh. Mas'ud, Jilid. 1, (Jakarta: Erlangga, 1994), h. 5.

Imron, M. (2002). konsep pelatihan : Skripsi UPI

Moleong, Lexy J. 2007. Metodologi Penelitian Kualitatif. Edisi Revisi. Bandung : PT Remaja Rosdakarya.

Purwanto, Heri (2007). Ortopedagogik Umum

Samsuni, samsuni (2017) Manajemen sumber daya manusia. Banjarbaru: STAI Al Falah Banjarbaru

Sudjana, Djudju. 2006. Evaluasi Program Pendidikan Luar Sekolah Untuk Pendidikan NonFormal dan Pengembangan Sumber Daya Manusia. Bandung : PT Remaja Rosdakarya.

Sugiyono. 2008. Metode Penelitian Kuantitatif, Kualitatif, dan R\&D. Bandung : Alfabeta.

Tim BEE, Depdiknas. (2002). Pendidikan kecakapan hidup (Life Skills Education)

Utomo, H. (2015). Menumbuhkan Minat Kewirausahaan Sosial. 11(1), 159-182. https://doi.org/10.1002/sej 